\title{
PENGALAMAN BERAGAMA SUFI JALALUDDIN RUMI DALAM PERSPEKTIF PSIKOLOGI
}

\author{
Hajriansyah \\ Mahasiswa Pascasarjana Prodi Akhlak Tasawuf \\ IAIN Antasari Banjarmasin \\ E-mail: hajrian@yahoo.co.id. \\ Diterima tanggal 7 November 2014 / Disetujui tanggal 9 Desember 2014
}

\begin{abstract}
Sufi's poetry or the poetry of Islamic Mysticism is part of the cultural heritage of Islam. If the mention of the many names of Sufi poets, the most commonly known and easily referred to is the name of Maulana Jalaluddin Rumi or Rumi. This writing wants to frame the religious experience of Rumi, through his poetries that reflects the attitude of Sufi's doctrine, in the perspective of Sufi psychologhy. The conclusion was obtained that Rumi was from the type of prophetic religion, so that his attitude of the religion did not leave Syariat aspects which part of Islamic doctrine, although he put a lot of mystical attitude in his eccentric poems since his meeting with Syams Tabriz:
\end{abstract}

Kata kunci: Pengalaman Beragama, Rumi, dan Psikologi Sufi.

\section{Pendahuluan}

Jalaluddin Rumi (604-672 H/ 1207-1273 M) merupakan seorang penyair sufi Persia terbesar dalam sejarah. Meskipun sebelum dan sesudahnya, di Persia, terdapat banyak penyair sufi, namun Rumi dianggap berhasil mengungguli yang lainnya ditinjau dari syairnya dan cakupan kedalaman makna sufistik yang ada di dalamnya.

Persia memang merupakan sebuah daerah yang banyak melahirkan penyair sufi. Jauh sebelum Rumi, misalnya, Abu Said bin Abi al-Khair al-Khurasani (357-440 H) telah menyusun banyak sekali syair-syair sufi, dan memiliki pengaruh yang besar dalam mazhab Khurasan, salah satunya dalam hal pelembagaan khanaqah di mana puisi, sama', dan tarian sufi menjadi ritual ketaatan kolektif para sufi dalam hal mengingat Tuhan. Kemudian, ada Abdullah al-Ansari (w. $481 \mathrm{H}$ ) yang mempunyai diwan tentang syair-syair sufi, juga Majduddin Sana'i al-Ghaznawi (w. $545 \mathrm{H}$ ) yang telah menyusun al-Matsnawi yang dikenal dengan sebutan Taman Hakikat, dan nazham-nazham lainnya. Selain itu, ada juga Fariduddin Attar $(586 \mathrm{H})$ yang sangat terkenal dengan Mantiq al-Thayr-nya, yang mempunyai karya tidak kurang dari 40 buah. Dan ketika datang Jalaluddin Rumi yang merupakan syekh para penyair sufi, maka semuanya itu dapat terungguli olehnya. ${ }^{1}$

Lebih dari itu, bahkan setelah kematian Rumi, Persia tetap menjadi ladang persemaian syairsyair para penyair sufi besar. Salah satu dari penyair-penyair yang datang setelah Rumi adalah Sa'duddin Mahmud Syabistari (w. 1340 M). Ia adalah pemilik diwan Gulshan-i-Raz (Kebun Mawar Rahasia), yang dianggap sebagai syair Persia yang mengandung pengetahuan-pengetahuan spiritual yang terperinci. Selain itu, ada pula seorang penyair sufi yang bernama Hafizh Syairazi (Khwaja Syamsuddin Muhammad Hafizh al-Syirazi, w. 791 H/ 1390 M). Ia terkenal dengan keindahan syair-syair sufi dan

${ }^{1}$ Abu Wafa' al-Ghanimi al-Taftazani, Tasawnf Islam: Telaab Historis dan Perkembangannya (Jakarta: Gaya Media Pratama, 2008), 277. 
ghazal ciptaannya, yang mengungguli syair-syair lainnya dari tinjauan keindahan dan kedetailan sebuah syair. Selain mereka, ada lagi penyair Abdurrahman al-Jami (w. 898 H/ 1492 M). Ia dianggap sebagai penyair sufi yang sangat besar dan salah seorang jenius dari Persia.

Di antara sekian banyak penyair sufi besar, sebelum maupun sesudahnya, Rumi adalah raksasa yang sulit ditandingi kebesarannya. Tidak hanya sebagai penyair sufi, kehadirannya sebagai guru spiritual pelindung Konya-bahkan hingga ke Samarkand dan Bukhara-masih dirasakan hingga kini, sebagaimana dikisahkan sangat antusias oleh Annemarie Schimmel dalam "Akulah Angin Engkaulah Api”.

Syair-syair mistiknya tidak hanya menginspirasi para salik (sufi) dari kalangan orang-orang Islam sepanjang zaman, bahkan lebih dari itu memanggil para pencari Tuhan dari beragam agama dan aliran kepercayaan yang hingga kini menziarahi Konya, tempat berpulangnya tujuh abad yang silam.

\section{Mari ke rumabku, Kekasih_sebentar saja! \\ Gelorakan jiwa kita, Kekasib_sebentar saja! \\ Dari Konya pancarkan cahaya Cinta \\ Ke Samarkand dan Bukhara sebentar saja! ${ }^{2}$}

\section{Biografi Maulana Jalaluddin Rumi}

Jalaluddin Muhammad ibn Muhammad al-Balkhi al-Qunawi merupakan nama lengkap dari Jalaluddin Rumi. Ia lahir di Balkh pada tanggal 6 Rabiul Awwal 604 H, atau, bertepatan dengan tanggal 30 September 1207 M. Ayah Rumi, Bahauddin Muhammad atau yang lebih dikenal sebagai Bahauddin Walad, adalah seorang cendikiawan yang saleh, mistikus yang berpandangan ke depan, dan seorang guru yang terkenal di Balkh.

Schimmel, dengan merujuk kepada Fritz Meier, mengoreksi catatan yang umum ini dengan menyebutkan bahwa rumah mereka bukan di kota Balkh-karena pusat Islam pada pertengahan abad ke-8 adalah di Khurasan (sekarang Afghanistan)—melainkan tepatnya di kota kecil Wakhsyi, sebelah utara Oxus, tempat Bahauddin Walad tinggal dan bekerja sebagai hakim dan khatib dengan kecenderungan yang mengarah ke tasawuf. Dia (Bahauddin Walad) dapat memutuskan perkara dan memiliki kekuatan melihat hal-hal yang belum terjadi, dan yang ada di balik sesuatu, walaupun tidak pernah menjadi seorang sufi dalam arti yang lazim. ${ }^{3}$ Schimmel juga menambahkan bahwa Wakhsy, yang secara budaya merupakan bagian dari Balkh, adalah bagian dari kekuasaan Ghuriyyah yang makin lemah karena segera diserang oleh Khwarizmsyah. Ketika Jalaluddin berusia lima tahun, ayahnya hijrah ke Samarkand, meninggalkan ibunya yang sudah tua. Kota itu kemudian dikepung oleh Khwarizmsyah yang bermaksud memperluas wilayahnya ke seluruh Transoxiana sampai ke Hindu Kusy. Dan, dalam salah satu cerita yang ada pada Fibi Ma Fibi, diceritakan tentang pengepungan ini dan bagaimana kekuatan doa seorang wanita dapat melindunginya dari perbuatan keji musuh. ${ }^{4}$

Ayah Rumi, Muhammad yang bergelar Bahauddin Walad juga bergelar Sulthan al-Ulama, nasabnya bersambung sampai kepada Abu Bakar al-Shiddiq, salah seorang sahabat terpercaya Nabi saw. dan merupakan Khalifah Islam yang pertama. Menurut riwayat, salah seorang putra atau cucu Abu Bakar adalah salah seorang di antara orang-orang Arab yang menaklukkan Khurasan pada masa

\footnotetext{
${ }^{2}$ Annemarie Schimmel, Akulah Angin Engkaulah Api: Hidup dan Karya Jalaluddin Rumi (Bandung: Mizan, 2008$), 1$. ${ }^{3}$ Schimmel, Akulah Angin Engkaulah Api, 15.

${ }^{4}$ Schimmel, Akulah Angin Engkaulah Api, 16.
} 
kekhalifahan Utsman ibn Affan, sekitar tahun 25 Hijriyah, yang kemudian bermukim di Balkh.

Dalam catatan kaki pada bagian "Silsilah Jalaluddin Rumi”, disebutkan bahwa dalam pengantar berbahasa Turki dari salinan Matsnawi terdapat silsilah yang mengusut asal Jalaluddin Muhammad dari Abu Bakar, dalam sepuluh derajat, sebagaimana berikut: Jalaluddin Muhammad ibn Bahauddin Muhammad ibn Husayn ibn Abmad ibn Mawdud ibn Tsabit ibn Musayyab ibn Muthahhar ibn Muhammad ibn Abdurrahman ibn Abu Bakar al-Shiddiq. Namun masih di bagian yang sama, si penulis (penerjemah) lalu langsung menyangsikan silsilah ini. Karena menurutnya, andaikata nama-nama itu benar, maka banyak mata rantai lain tentunya akan hilang-barangkali sebanyak yang dikemukakan tersebut, mengingat bahwa rentang masa antara Abdurrahman ibn Abu Bakar yang meninggal dan dimakamkan di Mekkah pada tahun 53 H (672 M) dengan kelahiran Jalaluddin pada tahun 604 H (1207 M) ada jarak sekitar 535 tahun, dengan sembilan derajat keturunan berarti masing-masing keturunan setidaknya berumur 66 tahun sebelum kelahiran keturunan berikutnya. Meski begitu, catatan ini tetap penting untuk diungkapkan untuk memberikan wawasan dan kemungkinan penelusuran lebih jauh. ${ }^{5}$ Dari garis keturunan ibunya, Rumi juga merupakan keturunan sepupu, sahabat dan menantu Nabi saw., Ali ibn Abi Thalib yang merupakan Khalifah Islam yang keempat. ${ }^{6}$

Karena pertentangan politik dalam negeri dan invasi bangsa Mongol, Bahauddin Walad, ayah Rumi, mengungsi bersama seluruh keluarganya dan beberapa muridnya menuju ke Barat kira-kira pada tahun 617 H/ 1220-1 M. Di Naisyabur rombongan ini bertemu penyair sufi terkenal, Fariduddin Attar. Diceritakan bahwa Syekh Attar mengunjungi Bahauddin dan kemudian memberikan sebuah buku, Asrar Namah, kepada Rumi kecil seraya berkata kepada ayahnya, "nanti anakmu ini akan menjadi tokoh yang menyalakan api spiritual di dunia."” Dari Naisyabur keluarga ini terus menuju Baghdad dan bertemu dengan beberapa ulama dan sufi di kota ini, lalu melanjutkan perjalanan ke Hijaz dan ke Mekkah untuk menunaikan ibadah haji. Setelah itu, atas undangan Alauddin Kaikobad, penguasa Saljuk Rum (Anatolia), Bahauddin dan keluarganya datang ke Asia Kecil dan akhirnya menetap di Konya sebagai seorang ulama yang disegani hingga akhir hayatnya, saat Jalaluddin berusia 24 tahun.

Meskipun Jalaluddin dekat dengan ayahnya, khususnya dalam bidang ilmu pengetahuan eksoteris karena ia dipersiapkan menjadi seorang guru, kata Nasr, sebenarnya kematian ayahnya-lah yang memaksa Jalaluddin menggantikan kedudukannya sebagai seorang ahli agama yang berwenang memberikan fatwa mengenai masalah yang berkaitan dengan syariah. Selama setahun penuh dia mencurahkan perhatiannya dalam hal ini, sampai dia bertemu dengan Burhanuddin Muhaqqiq Tirmidzi—seorang guru sufi mumpuni yang juga merupakan murid ayahnya, Bahauddin Walad. Melalui Burhanuddin inilah Rumi mewarisi ajaran spiritual ayahnya, yang merupakan seorang syekh tarekat Kubrawiyah.

Dikatakan di dalam Manaqib al-'Arifin karya Syamsuddin Ahmad al-Aflaki, murid Rumi, sanad keguruan (tarekat) Rumi bisa ditelusuri dari Sayyid Burhanuddin Tirmidzi ke Bahauddin Walad, kemudian ke Imam Sarakhsi, ke Akhmad al-Khatibi (kakek dari ayah Rumi), ke Muhammad ibn

${ }^{5}$ Lebih lanjut bisa dilihat pada Syamsuddin Ahmad al-Aflaki, Tebaran Hikmab: Hikayat-bikayat di Seputar Jalaluddin Rumi, terjemahan dari The Legend of the Sufis: Selections from Manaqib al-'Arifin (Bandung: Al-Bayan, 1998), 15-16.

${ }^{6}$ Lihat Iqbal M Ambara, Rumi Sang Sufi Humanis (Yogyakarta: Penerbit Lukita, 2010), 11.

${ }^{7}$ Meskipun kisah pertemuan dengan Attar ini merupakan cerita yang populer, dan dikutip oleh Seyyed Hossein Nasr pada bagian "Jalal al-Din Rumi: Penyair dan Sufi Agung Persia” dalam Spiritualitas dan Seni Islam, namun banyak diperdebatkan oleh para ahli, terutama jika mengingat Taftazani dalam Tasawuf Islam menyatakan kematian Attar pada tahun $586 \mathrm{H}$, sementara Rumi lahir pada tahun $604 \mathrm{H}$. Meski demikian, tetap ada peluang kemungkinan pertemuan itu, apalagi jika mengingat kisah kehidupan Attar yang cukup misterius dan silang pendapat tentang tahun kematiannya. 
Muhammad al-Ghazali, ke Abu Bakar ibn Abdullah al-Thusi, ke Abu 'Amr Muhammad ibn Ibrahim Zajjaj al-Naisyaburi, ke Syibli, ke Junaid al-Baghdadi, ke Sirri al-Saqati, ke Ma’ruf al-Karkhi, ke Dawud al-Thai, ke Habib al-Ajami, ke Hasan al-Bashri, ke Sayyidina Ali ibn Abi Thalib, ke Rasulullah saw.

Rumi secara spiritual berada di bawah bimbingan Burhanuddin selama kurang lebih sembilan tahun, sampai gurunya ini wafat pada tahun 638 H/ 1240-1. Di antara masa sembilan tahun itu pula, Rumi yang haus akan pengetahuan melanjutkan studi keagamaan formal di madrasah Halawiyah di Aleppo hingga dia menjadi seorang yang mumpuni dalam banyak bidang keilmuan, seperti tafsir, hadis, fikih, teologi, dan filsafat. Dalam periode itu pula Rumi melakukan perjalanan ke Damaskus, dan sempat menetap di kota ini selama kurang lebih empat tahun. Beberapa sumber menyatakan tentang pertemuan Rumi dengan tokoh besar tasawuf Ibn 'Arabi, yang menghabiskan masa akhir hidupnya di Damaskus. ${ }^{8}$

Kembali ke Konya setelah pengembaraan keilmuannya, Rumi kemudian mendirikan madrasah di sekitar kediamannya, dan sejak tahun 638 hingga $642 \mathrm{H}$ ia disibukkan pengajaran keagamaan bagi murid-muridnya yang menurut sebagian ahli berjumlah ribuan, namun menurut Nasr sejumlah kirakira 400 orang pelajar menghadiri pendidikan formalnya. Hidup Rumi berubah secara drastis, dari seorang guru agama dan spiritual yang formal menjadi seorang penyair sufi yang eksentrik, ketika berjumpa dengan seorang tokoh sufi misterius yang dikenal sebagai Syams Tabriz atau Syamsuddin al-Tabrizi pada tahun $642 \mathrm{H} / 1244-5 \mathrm{M}$.

Perjumpaan dengan Syams Tabriz ini dikisahkan dalam banyak riwayat terjadi secara dramatis dan penuh nuansa spiritual. Dikisahkan, sufi pengembara itu hadir di tengah pengajaran Rumi kepada murid-muridnya dan bertanya, "Siapakah yang lebih agung, Muhammad Rasulullah atau sufi dari Persia, Bayazid Bistami? Bayazid pernah mengatakan, 'subhani (mahasuci diriku)', sementara Rasulullah telah mengucapkan dalam doanya kepada Allah Swt., "kami tidak mengenal-Mu seperti seharusnya"'.

Ada beberapa versi yang berbeda tentang pertemuan pertama yang menginspirasi kehidupan kepenyairan Rumi sepanjang hidupnya yang kemudian itu. Ada yang mengatakan bahwa pertemuan terjadi di pasar saat Rumi tengah bersama murid-muridnya, riwayat yang lain mengatakan pertemuan terjadi di madrasah saat Rumi tengah mengajar, ada juga yang menyatakan bahwa efek dari pertanyaan itu sangat dahsyat hingga Rumi tak sadarkan diri dan pingsan, namun ada pula riwayat yang menyatakan bahwa jauh sebelum terjadi di Konya mereka pernah bertemu di Damaskus namun tidak saling bertegur sapa. Manapun dari cerita-cerita itu yang benar, yang jelas bahwa kehidupan Rumi benar-benar berubah sesudahnya.

Rumi seakan melihat cahaya kebenaran melalui figur Syams Tabriz, sajak-sajak kerinduannya kepada Syams merupakan ungkapan sekalian metafor kerinduannya akan Kebenaran (Tuhan) itu sendiri. Ia bahkan mengarang Diwan-i Syams-i Tabriz yang berisi sajak-sajak kerinduan akan ketuhanan yang berisi 36 ribu bait. Syamsuddin al-Tabrizi adalah semacam gelar, yang artinya "Matahari dari Tabriz", sedangkan nama aslinya sebagaimana disebutkan al-Aflaki adalah Muhammad ibn Ali ibn Malik Dad. Perjumpaan Rumi dengannya berlanjut dengan persahabatan yang sangat dekat, sebagaimana guru spiritual dan muridnya, hingga mereka berdua mengasingkan diri dari orangorang selama kurang lebih tiga bulan. Setelah itu ia menghilang. Beberapa tahun kemudian mereka

${ }^{8}$ Bagaimanapun juga hal ini sulit dibuktikan secara historis. Namun begitu, kata Nasr, tidak diragukan bahwa kedua tokoh besar tasawuf ini tentu "bertemu" di alam ghaib sekalipun mereka tidak pernah bertemu secara jasmani. Lihat Seyyed Hossein Nasr, Spiritualitas dan Seni Islam (Bandung: Penerbit Mizan, 1993), 130.

${ }^{9}$ Schimmel, Akulah Angin Engkaulah Api, 21-22. 
bertemu kembali di Damaskus dan Rumi mengajaknya kembali ke Konya, namun tak lama kemudian menghilang lagi untuk selamanya. Sultan Walad, putra dan penerus Rumi, pernah berkomentar tentang hubungan ayahnya dan Syams Tabriz:

"Sesungguhnya, seorang guru besar tiba-tiba menjadi seorang murid kecil. Setiap hari sang guru besar harus menimba ilmu darinya, meski sebenarnya beliau cukup alim dan zuhud. Tetapi itulah kenyataannya. Dalam diri Tabriz, guru besar itu melihat kandungan ilmu yang tiada taranya." ${ }^{10}$

Sesudah kepergian Syams Tabriz, sahabat terdekat Rumi adalah Shalahuddin Faridun Zarkub, seorang penempa emas yang bersahaja, yang pernah menjadi murid dari Sayyid Burhanuddin Tirmidzi bersama Rumi. Selain sebagai sahabat, murid sekaligus guru Rumi, Syekh Faridun juga merupakan besannya. Ia menikahkan putrinya, Fatimah, dengan anak sekalian penerus Rumi, Sultan Walad. Setelah menemani Rumi selama kurang lebih sepuluh tahun, Shalahuddin meninggal pada tahun $657 \mathrm{M} /$ $1258 \mathrm{M}$ dan disemayamkan dengan iringan musik sufi seperti keinginannya.

Seperti dikatakan Nasr, Rumi adalah tipe sufi yang membutuhkan persahabatan spiritual dalam rangka mengekspresikan dirinya melalui kata-kata. ${ }^{11}$ Segera setelah kematian Syekh Faridun, Rumi mendapatkan sahabat yang berperan sebagai guru sekaligus murid penerusnya, yaitu Husamuddin Chalabi. Ia berasal dari Urmia, ayahnya adalah seorang Syekh Tarekat Fatuwwah. Peranan Husamuddin bagi Rumi dalam penggubahan Matsnawi sangat penting, sebagaimana Syams dalam Diwan. Dengan kata lain, apabila Syams Tabriz merupakan sebab eksternal dalam penggubahan Diwan-i Syams-i Tabriz, Husamuddin berperan sebagai galah yang menarik dan membawanya ke dalam penggubahan rapsodi syair mistik yang melimpah ruah, yang dinamakan Matsnawi. ${ }^{12}$

Husamuddin adalah penerus tarekat Rumi, yang menjadi ayah spiritual bagi Sultan Waladsebelum ia menggantikan peran ayahnya dan digantikan kemudian oleh anaknya Amir 'Arif (cucu Rumi) yang merupakan guru dan sahabat al-Aflaki-dan murid-muridnya yang lain. Diceritakan oleh al-Aflaki bahwa suatu hari Husamuddin bersama sahabat dan murid-muridnya berziarah ke makam Rumi. Tak disangka, bulan sabit bersepuh emas yang ada di atas kubah Rumi telah jatuh. Hal ini, bagi Husamuddin, adalah makna tersendiri, sepuluh tahun telah berlalu sejak kematian Rumi, dan itu adalah isyarat bagi hidupnya. Beberapa hari kemudian setelah ziarah, pada hari Kamis 22 Sya'ban 683 H (4 Nopember 1284 M), Husamuddin menghembuskan napasnya yang terakhir, tepat ketika bulan sabit bersepuh emas di atas makam Rumi diganti, dan pemasangannya hampir selesai. ${ }^{13}$

\section{Jalaluddin Rumi dalam Bingkai Psikologi Sufi}

Dalam The Varieties of Religious Experience, William James menegaskan bahwa agama, dalam konteks psikologi, adalah perasaan, tindakan, dan pengalaman setiap orang dalam kesendiriannya, seiring pemahamannya dalam bersikap yang berhubungan dengan apa saja yang mereka anggap sebagai Tuhan. ${ }^{14} \mathrm{Hal}$ ini (pengalaman beragama yang personal) berdasarkan kenyataan, katanya, cenderung membuat manusia menjadi pribadi yang unik dan eksentrik.

Pengalaman eksistensial, atau dalam frasa lain 'waktu psikologis', melibatkan aspek batin jiwa manusia, emosional dan mental. Pengalaman ini, dikatakan oleh Ujam Jaenudin dalam "Psikologi

${ }^{10}$ Abul Hasan al-Nadwi, Jalaluddin Rumi Sufi Penyair Terbesar, diterjemahkan dari Maulana Jalaluddin Rumi (Jakarta: Pustaka Firdaus, 2004), 5.

${ }^{11}$ Nasr, Akulah Angin Engkaulah Api, 131.

${ }^{12} \mathrm{Nasr}$, Akulah Angin Engkaulah Api, 134.

${ }^{13} \mathrm{Al}$-Aflaki, Tebaran Hikmah, 139.

${ }^{14}$ William James, The Varieties of Religious Experience (Pengalaman-pengalaman Religius) (Yogyakarta: Jendela, 2003$), 39$. 
Transpersonal", ${ }^{15}$ bukanlah pengalaman sebagaimana yang dikonsepsikan oleh akal, melainkan pengalaman yang dirasakan dan dialami. Dan seperti ditegaskan oleh Nicholson, dari Jalaluddin kita mendapatkan (tentang) perasaan, keyakinan, dan pengalaman keagamaan personal. ${ }^{16}$

Inilah kehidupan yang berjiwa agamis, kata Nicholson, yang pada intinya demi bersatu dengan Tuhan, berkontemplasi dengan-Nya pada saat susah dan senang, sebagaimana yang dilakukan oleh Jalaluddin Rumi.

Ob Engkau adalah yang melipur jiwaku pada saat resah,

Ob Engkau adalah yang memberi semangat hatiku pada pada

saat mendapatkean kepabitan,

Itulah khayalan yang tak dapat dipahami, itulah pemahaman

yang tak dapat dilihat.

Singgablah rub-Mu dalam rubku, karenanya, di dalam ibadah,

aku kembali ke hadapan-Mu. ${ }^{17}$

Masih di dalam Diwan-i Syams-i Tabriz (dalam Nicholson) Rumi berkata:

Engkau Sendiri yang yang memilibku di alam mayapada ini,

Akankah Engkau menyengsarakanku dalam kesedihan?

Hatiku laksana pena dalam genggaman tangan-Mu,

Engkau adalah Penyebab-Nya, jika aku sedih atau murung.

Kecuali apa yang Kau kehendaki, apa yang bisa aku kehendaki?

Kecuali apa yang Kau tunjukkan, apa yang aku lihat?

Jika Engkau memeliharaku, maka itulah aku;

Jika Kamu menjadikanku Sesuatu, maka aku adalah sesuatu.

Dalam bejana itulah, tempat di mana Engkau memberikan warna

dalam jiwaku,

Siapa aku? Apa yang Engkau cinta dan apa yang Engkau benci?

Ketika Engkau bersembunyi, maka aku adalah orang kafir, ketika

Engkau tampak, maka aku adalah orang Mukmin. ${ }^{18}$

Dalam hal menyikapi pertanyaan tentang kejahatan, kesedihan dan dosa, Rumi mengatakan dalam Matsnawi (dikutip dari Nicholson), "Jika kamu tidak mengetahui Iblis (kejahatan), maka lihatlah dalam dirimu". Hal ini, mengingat Rumi juga seorang ulama, menunjukkan betapa ia memperlakukannya dalam bentuk yang praktis dan mudah dipahami. Kejahatan bukanlah sesuatu yang menjadi lawan dari "keberadaan" Tuhan, dan saat ia (manusia) mengetahui bahwa semuanya sungguh tidak ada kaitannya dengan Tuhan, maka dia sadar bahwa pada kenyataannya semuanya kembali kepada manusia.

Hendaklah kamu malu dengan dosamu, akui semuanya di hadapan Tuhan dengan rendah hati, mintalah ampun atas dosadosamu pada Tuhan, dan ubahlah hatimu untuk membenci terhadap apa yang telah kamu lakukan, lalu tinggalkanlah semuanya. ${ }^{19}$

\footnotetext{
${ }^{15}$ Ujam Jaenudin, Psikologi Transpersonal (Bandung: Pustaka Setia, 2012), 181.

${ }^{16}$ Reynold A. Nicholson, Gagasan Personalitas dalam Sufisme (Yogyakarta: Pustaka Sufi, 2002), 76.

${ }^{17}$ Nicholson, Gagasan Personalitas dalam Sufisme, 78.

${ }^{18}$ Nicholson, Gagasan Personalitas dalam Sufisme, 80.

${ }^{19}$ Nicholson, Gagasan Personalitas dalam Sufisme, 80-81.
} 
Hal ini sejalan dengan apa yang dinyatakan oleh A. Reza Arasteh, bahwa seorang sufi memiliki cara yang lebih baik untuk mentransformasikan kepribadian konvensional menuju kepribadian sejati. Tidak seperti psikoanalisa, katanya, tasawuf menggunakan perilaku keagamaan, bertugas memurnikan dan merubah nilai-nilai yang palsu dan kepentingan yang salah. ${ }^{20}$

Tujuan Sufisme sangat berbeda dengan tujuan psikologi. Dalam "analogi lampu”, seperti dinyatakan Lynn Wilcox, bahwa sufisme menitikberatkan adanya hubungan dengan Sumber Energi yang akan membuat lampu itu bercahaya. Tujuan simbolik ini meliputi dua tujuan, yakni mengembangkan manusia yang sempurna dan mengembangkan masyarakat yang sempurna.

Secara simbolik, tujuan Sufisme juga dituliskan dengan bahasa yang puitis dalam berbagai bentuk: sebagai letupan panas yang binasa di tengah bara api, sebagai tetesan air yang menjadi lautan Wujud, dan yang paling sering, sebagai kesatuan dari Yang Terkasih, (yakni) Tuhan. ${ }^{21}$

\author{
Asap yang menari bersama cinta- \\ Wabai Kekasih, dekap aku seperti asap yang menari itu \\ Panas yang membakar dalam api \\ Wahai Kekasih, dekap aku seperti panas membakar api \\ … \\ Wahai Kekasih, dekap aku seperti para pecinta luapkan cinta \\ Penyatuan diri bagaikan sungai yang mengalir dengan sepenuh godaan menuju laut \\ Malam nanti bulan akan mencium bintang-bintang \\ Majnun menjelma Laila - \\ Wabai Kekasih, dekap aku seperti mereka \\ Tuhan adalah segalanya \\ Ia menganugerahi kebaikan bagi penyair itu \\ Segala yang kusentuh dan kulihat berubah menjadi nyala cinta ${ }^{22}$
}

Hati bagi seorang sufi adalah terminal tempat ia berangkat menuju Tuhan dalam perjalanan spiritual yang panjang. Hati juga disebut sebagai "Pusat Spiritual", dengan demikian yang dimaksud bukanlah hati dalam definisi teknis biologis, melainkan hati spiritual. Menurut psikologi sufi, hati menyimpan kecerdasan dan kearifan manusia yang terdalam; ia lokus ma'rifat, gnosis, atau pengetahuan spiritual. ${ }^{23}$ Rumi menyatakan dengan sebait puisi yang menyejukkan hati:

\author{
Sejak kudengar dunia Cinta \\ Kuserabkan bidupku, batiku \\ dan mataku di jalan ini \\ Mulanya, aku meyakini babwa cinta
}

${ }^{20}$ A. Reza Arasteh, Revolusi Spiritual (Metode Mengembangkan Kepribadian Sufi: Aktualisasi Diri Fitri), diterjemahkan dari Growth to Selfhood: the Sufi Contribution (Depok: Inisiasi Press, 2002), 10.

${ }^{21}$ Lynn Wilcox, Psikologi Kepribadian (Analisis Seluk-beluk Kepribadian Manusia), diterjemahkan dari Criticism of Islam Psychology, (Yogyakarta: Ircisod, 2013), 55 \& 57.

${ }^{22}$ Jalaluddin Rumi, Jalan Menuju Cinta, terjemahan dalam bahasa Inggris oleh Jonathan Star, In the Arms of the Beloved (Yogyakarta: Terompah, 2000), $54 \& 55$.

${ }^{23}$ Robert Frager, Psikologi Sufi (Untuk Transformasi Hati, Jiwa, dan Rub), diterjemahkan dari Heart, Self \& Soul: The Sufi Psychology of Growth, Balance, and Harmony (Jakarta: Zaman, 2014), 32. 
dan yang dicintai adalah berbeda

Kini, kupahami mereka adalah sama

Aku melihat keduanya dalam kesatuan ${ }^{24}$

Di dalam puisi yang lain, Rumi juga berkata:

Wabai cinta

Wahai hati

Temukan jalan menuju surga

Temukan jalan menuju padang gembala Tuban

Telah kau babiskan waktu di padang gembala hewan ternak ini

$\cdots$

Tenanglah sekarang, wahai hati

Dengarkanlah firman Pencipta dunia

Ia telah membuat pintu

Ia pun telah membuat lubang kunci di pintu itu

Ia pun telah membuat anak kunci untuk membukany $a^{25}$

....

Wabai hati

Ciptakanlah harapan-harapan sebab pemberian telah disiapkan

Sang Raja telah menunggumu dengan tangan pemurabnya yang terbuka

Cahaya wajah-Nya akan menyinari dirimu...${ }^{26}$

Annemarie Schimmel dalam pengantarnya untuk John Renard menyatakan bahwa, ada kecenderungan yang meningkat di kalangan para sarjana Barat, dan bahkan lebih banyak lagi di kalangan pecinta dan pengagum Rumi, untuk melupakan latar belakang Islami puisi Jalaluddin Rumi. Lebih lanjut Schimmel menulis:

"Peranan Nabi Islam yang dihadirkan dalam puisi Maulana (Rumi) hampir tidak disebut-sebut dalam kesusasteraan sekunder. Namun, siapa pun yang menyimak na'ti-i syarif, yaitu penggalan musik pengantar pada permulaan upacara-upacara (mengenai) Maulawi, pasti akan merasa, bahkan mengetahui, betapa dalamnya cinta penyair ini kepada Nabi Muhammad. ... Nabi adalah orang yang rahasia-rahasianya dikomunikasikan melalui Syams-i Tabrizi, seorang sahabat mistikus yang penuh hikmah. Dan karena Muhammad adalah orang terakhir dari barisan para nabi yang menerima wahyu Tuhan sejak Adam hingga 'Isa, maka menjadi kewajiban kaum mukmin untuk mengakui dan menghormati para pembawa risalah Ilahi di masa-masa lampau tersebut. Jadi riwayat mereka, sebagaimana yang telah diriwayatkan atau disinggung dalam Alqur'an, merupakan bagian dari keseluruhan keimanan muslim." ${ }^{27}$

Dengan demikian jelas, meskipun pengalaman personal keagamaan Rumi menjadikannya unik dan eksentrik, ini tidak serta merta menafikan aspek-aspek kepercayaan agama (Islam) yang bersifat eksoteris, bahkan termasuk di dalamnya hal syariat sebagaimana terwujudkan dalam, salah satunya,

\footnotetext{
${ }^{24}$ Frager, Psikologi Sufi, 49.

${ }^{25}$ Rumi, Jalan Menuju Cinta, 59.

${ }^{26}$ Rumi, Jalan Menuju Cinta, 61.

${ }^{27}$ John Renard, Rajawali Sang Raja: Senandung Rumi tentang Nabi dan Wabyu, diterjemahkan dari All the King's Falcon: Rumi on Prophets and Revelation (Jakarta: Serambi, 2001), 9-10.
} 
shalat. Shalat merupakan salah satu ciri terpenting dalam karya Maulana, kata Schimmel. Dalam Matsnawi, misalnya, ada bagian-bagian di mana Rumi menggambarkan berbagai aspek dalam shalat: wudhu, menghadap kiblat, takbir, doa, dan seterusnya. ${ }^{28}$

Sepanjang hidupnya, Jalaluddin Rumi tercatat sebagai pribadi yang rajin, tekun, pintar, alim dan banyak beribadah. Sabah Salar, atau dalam tulisan Schimmel Sipahsalar-salah seorang penulis biografi Rumi, menuturkan bagaimana sang guru menghabiskan satu malam dengan shalat di masjid. Dalam An-Nadwi diceritakan, jika waktu shalat hampir tiba, ia segera bergegas menghadap kiblat. Air mukanya menjadi berubah dan tampak khusuk. Dikatakan, ia lama "tenggelam" dalam shalat.

Tentang kekhusukan Rumi dalam shalatnya, Sabah Salar berkata: "Acapkali saya melihat ia melalukan shalat Isya. Semalam penuh ia habiskan dalam raka'at.'Di dalam puisinya, Rumi melukiskan shalatnya yang khusuk dan tertib dengan sangat indah, yang demikian menggambarkan dan membuktikan bahwa sikapnya dalam shalat layaknya orang yang tengah kasmaran dan hampir-hampir tidak ingat diri. ${ }^{29}$

Pada saat shalat Isya

semua orang menggelar kain dan lilin

Namun aku memimpikan kekasibku,

menatap, sembari meratap dan sedih, isyaratnya

Dengan menangis, berarti aku melakukan wudhu,

dan shalatku akan bergelora,

Lalu kubakar jalan masuk masjid

ketika suara azanku berkumandang ....

Apakah shalatnya si mabuk,

katakanlah, sabkah shalat ini?

Sebab dia tak tahu waktunya

dan tak tahu tempat.

Apakah aku shalat dua raka'at penub?

barangkali ini kedelapan?

Surah mana yang kubaca?

Karena aku tak punya lidah untuk membacanya.

Di pintu Tuban—mana mungkin aku mengetuknya,

Karena kini aku tak punya tangan atau bati?

Tuhan, Dikau telah membawa hati dan tangan!

Tuhan, anugerabi daku keselamatan,

ampuni daku .... ${ }^{30}$

\section{Penutup}

Maulana Jalaluddin Rumi adalah seorang penyair mistikus (sufi) Islam yang sangat besar, hingga kini jika orang-orang menyebut penyair sufi Islam, maka yang pertama dikenang orang adalah Rumi.

\footnotetext{
${ }^{28}$ Lebih jauh lihat catatan Scimmel beserta puisi-puisi Rumi yang ia sertakan pada bab 9 "Shalat: Anugerah Ilahi” dalam Akulah Angin Engkaulah Api, 222-236.

${ }^{29} \mathrm{Al}-\mathrm{Nadwi}$, Jalaluddin Rumi Sufi Penyair Terbesar, 11.

${ }^{30}$ Schimmel, Akulah Angin Engkaulah Api, 222-223.
} 
Meski begitu seperti dikatakan Scimmel, Maulana Rumi adalah seorang sufi dan penyair yang berasal dari jenis agama profetik maupun mistis, dan bagian pertama dari dua aspek ajarannya inilah (agama profetik dengan segala aspek syariatnya) yang sering diabaikan.

Segera setelah pertemuannya dengan Syams Tabriz, Rumi berubah total, dari seorang ulama tasawuf yang formal menjadi seorang penyair sufi yang unik dan eksentrik. Puisi-puisinya merupakan luapan perasaan sekaligus ungkapan pengalaman keberagamaannya yang personal, yang lahir dari hati yang merindukan per(ny)satuan diri dengan Sang Kekasih. Sampai ketika Wujud Kekasih menjadi satu-satunya wujud yang ada—seperti diisyaratkan al-Taftazani, bahwa Rumi merupakan penyair sufi yang meneruskan paham kesatuan wujud (Wabdatul Wujud). Namun demikian, kesatuan baginya tidak seperti kesatuan dalam pemikiran Ibn 'Arabi yang menyatukan antara al-Haq dan makhluk. Dikatakan, hendaklah melihat metafora-metafora penyatuannya (Rumi) dalam kerangka persepsi imajiner, sebagai seorang sufi yang "tenggelam” dalam Lautan Kekasih.

\section{DAFTAR PUSTAKA}

Al-Aflaki, Syamsuddin Ahmad. Tebaran Hikmah: Hikayat-bikayat di Seputar Jalaluddin Rumi, diterjemahan dari The Legend of the Sufis: Selections from Manaqib al-'Arifin. Bandung: Al-Bayan 1998.

Al-Nadwi, Abul Hasan. Jalaluddin Rumi Sufi Penyair Terbesar, diterjemahkan dari Maulana Jalaluddin Rumi. Jakarta: Pustaka Firdaus. 2004.

A. Nicholson, Reynold. Gagasan Personalitas dalam Sufisme. Yogyakarta:Pustaka Sufi. 2002.

Arasteh, A. Reza. Revolusi Spiritual (Metode Mengembangkan Kepribadian Sufi: Aktualisasi Diri Fitri, diterjemahkan dari Growth to Selfhood: the SufiContribution. Depok: Inisiasi Press. 2002.

Frager, Robert. Psikologi Sufi (Untuk. Transformasi Hati, Jiwa, dan Rub), diterjemahkan dari Heart, Self \& Soul: The Sufi Psychology of Growth, Balance, and Harmony. Jakarta: Zaman. 2014.

Jaenudin, Ujam. Psikologi Transpersonal. Bandung: Pustaka Setia. 2012.

James, William. The Varieties of Religious Experience (Pengalaman-pengalaman Religius). Yogyakarta: Jendela. 2003.

M. Ambara, Iqbal. Rumi Sang Sufi Humanis. Yogyakarta: Lukita. 2010.

Nasr, Seyyed Hossein. Spiritualitas dan Seni Islam, diterjemahkan dari Islamic Art and Spirituality. Bandung: Penerbit Mizan. 1993.

Renard, John. Rajawali Sang Raja: Senandung Rumi tentang Nabi dan Wabyu, diterjemahkan dari All the King's Falcon: Rumi on Prophets and Revelation. Jakarta: Serambi. 2001.

Rumi, Jalaluddin. Jalan Menuju Cinta, terjemahan dalam bahasa Inggris oleh Jonathan Star, In the Arms of the Beloved. Yogyakarta: Terompah. 2000.

Schimmel, Annemarie. Akulah Angin Engkaulah Api: Hidup dan KaryaJalaluddin Rumi, diterjemahkan dari I Am Wind, You Are Fire. Bandung: Mizan. 2008.

Al-Taftazani, Abu Wafa' al-Ghanimi. Tasawnf Islam: Telaah Historis dan Perkembangannya, diterjemahkan dari Madkhal ila al-Tasawnf al-Islami. Jakarta: Gaya Media Pratama. 2008.

Wilcox, Lynn. Psikologi Kepribadian (Analisis Seluk-beluk Kepribadian Manusia), diterjemahkan dari Criticism of Islam Psychology. Yogyakarta: Ircisod. 2013. 